\title{
WOMEN'S COOPERATION IN POLISH RURAL AREAS
}

\author{
Monika Wojcieszak ${ }^{1}$, Ph.D. \\ ${ }^{1}$ Department of Economics and Economic Policy in Agribusiness, Poznan University of Life Sciences
}

\begin{abstract}
The purpose of this paper is to present the role and importance of the Polish Farmers' Wives' Association, and to present the results of the author's own research into the financing of the associations' activity. This research is focused on analysing the activity of Polish women and the way they use EU funds in the context of rural women's associations. The author's own research was carried out in the Wielkopolska region (where the largest number of FWAs was recorded), and relied on a diagnostic survey questionnaire. The survey was conducted in January 2019. The figures collected were analysed with the use of selected statistical methods. This study provides a basis for further analyses. EU funds will certainly stimulate entrepreneurial activity among women in rural areas and will be an excellent stimulus for further action. In Poland, taking initiatives to establish the KGW is a little known phenomenon, but it is part of the concept of sustainable development. Thanks to legal changes, women can apply for EU funds, which they can use for various purposes, e.g. to promote local and regional dishes and cultural heritage. Creative activation of women in rural areas also increases their sense of entrepreneurship, which is important for them to enter public life and build cooperation between them.
\end{abstract}

Keywords: rural women, Poland, cooperation.

JEL code: Q13, Q10, Q19, Q01.

\section{Introduction}

In Poland, rural areas account for over $90 \%$ of the national territory. According to 2016 data of the Central Statistical Office, they are home to more than 1,410,600 farms, of which one quarter are run by women. Increasingly often, women become sole or co-owners of agricultural holdings, agritourism establishments, care facilities or enterprises. It is therefore highly important to address the particularities of female entrepreneurship, especially in rural areas. The role of women is increasingly mentioned in both domestic and international literature (e.g. "Situation of women in agriculture and rural areas. Specifics, standards, parities and expectations," a report by the FOCUS GROUP - CRSG, 2012; Report on the situation of women in rural areas of the EU (2007/2117(INI))) European Parliament). However, relevant research efforts must be continued. Currently, the European Union places a strong emphasis on highlighting the role and importance of women in rural areas, and takes measures to promote rural community associations. As an interesting example, the European Parliament resolution of April 5, 2011 on the role of women in agriculture and rural areas (Official Journal of the EU C296E/13 of 2 October 2012) stresses that in the medium term, women ought to be adequately represented in all political, economic and social bodies.

The interest in the role of women in rural areas is driven by the European Union's new concept for the development of remote areas, referred to as the multipurpose sustainable development model for rural areas. According to this concept, in addition to traditional agricultural activities, rural areas should also fulfil other important functions: the socio-cultural, recreational, residential and ecological function (Michalska 2013, Report Gender 2016, Piers and e.al. 2009, Report Policy Brief on Women's Entrepreneurship 2016). This implies the need to develop the service sector and make rural women socially and professionally active. In that context, rural women represent intellectual capital and other resources which, while still not fully exploited, gain new value (Davidova, e.al.2010, Banski 2015, Kozera 2014, Kaminska 2011, Sikorska-Wolak and Krzyzanowska, 2010, Tabor 2010, Sawicka 2010). Increasing the rural women's activity should include combining their family and professional

${ }^{1}$ e-mail:monika.wojcieszak@up.poznan.pl 
roles, and encourage their participation in the social and political life of local communities (Kozera, 2015).

The entrepreneurship of rural women could play a key role in their personal development and in local development. Very often, women are the ones who take the first steps towards establishing a non-agricultural business, thus contributing to the survival of households and to the vitality of rural areas. The situation of women changes continuously and is impacted both by themselves and by the multi-focused measures taken by the citizens, civic organizations, state governments and international institutions. The policy put in place by the European Union and Poland should therefore encourage the women to engage in rural projects implemented to strengthen the women's role and promote all kinds of female activity. According to EU reports, the women's potential is not sufficiently exploited under the rural policy. Issues such as increasing the women's activity, participation in the labour market and contribution to social capital are not appropriately emphasized in the national development policy and, as a consequence, in the rural development policy. In turn, the research conducted by the largest Polish paying agency (the Agency for Restructuring and Modernization of Agriculture who implements EU measures in Poland), by the Ministry of Agriculture and Rural Development, and by representatives of consultancy firms specializing in raising funds under the RDP suggest that women fail to fully seize the funding opportunities provided by the Union because of socio-cultural and psychological barriers. Therefore, in order to counteract this, Polish women may currently establish Farmer's Wives' Associations (FWA).

The purpose of this paper is to present the role and importance of the Polish FWAs, and to present the results of the author's own research into the financing of the associations' activity. The research task was to check what financial sources from the EU can be used by the FWAs in Poland and what these funds can be used for.

This paper relied on the desk research method. The author used the classic analysis of existing and strategic documents which served to ascertain the facts as well as for verification and presentation purposes. The selection of methods was determined by the availability of source materials, of which some were original in nature and some were secondary (reports, public statistics documents, literature dealing with food quality systems and issues related to funding for entities within the study period). Unpublished data delivered by the Agency for Restructuring and Modernization of Agriculture was related to EU subsidies for rural women's associations in Poland, as available under the 2014-2020 Rural Development Program. This research is focused on analysing the activity of Polish women and the way they use EU funds in the context of rural women's associations. The author's own research was carried out in the Wielkopolskie voivodeship (where the largest number of FWAs was recorded), and relied on a diagnostic survey questionnaire. The survey was conducted in January 2019. The figures collected were analysed with the use of selected statistical methods. This study provides a basis for further analyses.

\section{Research results and discussion}

Today, ca. 26,500 FWAs are active in Poland (Central Statistical Office, 2017). There is a dual basis for establishing an FWA. Firstly, FWAs may be established as part of what is referred to as Machinery Rings (Act of October 8, 1982 on social and professional organizations of farmers, Journal of Laws [Dz.U.] of 1982, No. 32, item 217). The second option is to create FWAs in rural areas under principles applicable to associations. The Polish legislation defines the Farmers' Wives' Association (abbreviated as FWA) as a voluntary, self-governing social organization of the rural population, which 
is independent from central and local government authorities, promotes rural entrepreneurship and actively supports the rural communities. Its core idea is to improve the social and professional status of rural women and their families. As another important aspect, the FWAs promote female entrepreneurship by engaging into socio-educational and cultural projects in rural communities. Also, the task of FWAs is to initiate and implement measures designed to improve the living and working conditions of rural women, promote and develop rational housekeeping methods and various forms of cooperation and farming, represent the interests of the rural women community before public administration authorities, and develop folk culture, especially including local and regional culture (Act of 9 November 2018 on the Farmers' Wives' Associations). As provided for in the Polish legislation, FWAs seek their goals using funds coming from the members' contributions, subsidies from the state budget or local government units, donations, inheritances, gifts, own revenues, revenues derived from their assets and public charity. FWAs may carry out remunerated activities and earn revenues from: the sale of folk art (including handicrafts and folklore or art products) or regional food; the sale, rental or lease of assets; interest on cash held in accounts kept by a bank or a credit union in connection with their activity, including interest on fixed-term deposits and other forms of savings, deposits or investments existing in these accounts (Act of November 9, 2018 on the Farmers' Wives' Associations). FWAs are allowed to carry out a remunerated activity, including an economic activity. The income derived from their activity will serve the objectives set out in the statute and cannot be distributed among members. Pursuant to the Act, only one FWA can be based in one village. Conversely, one FWA can operate in one or more villages. FWAs are also allowed to carry out tasks outside their territorial boundaries, including in the Republic of Poland or abroad. The Polish registration authority for FWAs is the Agency for Restructuring and Modernization of Agriculture. According to records kept by the Agency, there are currently over 4921 FWAs active in Poland (Fig. 1).

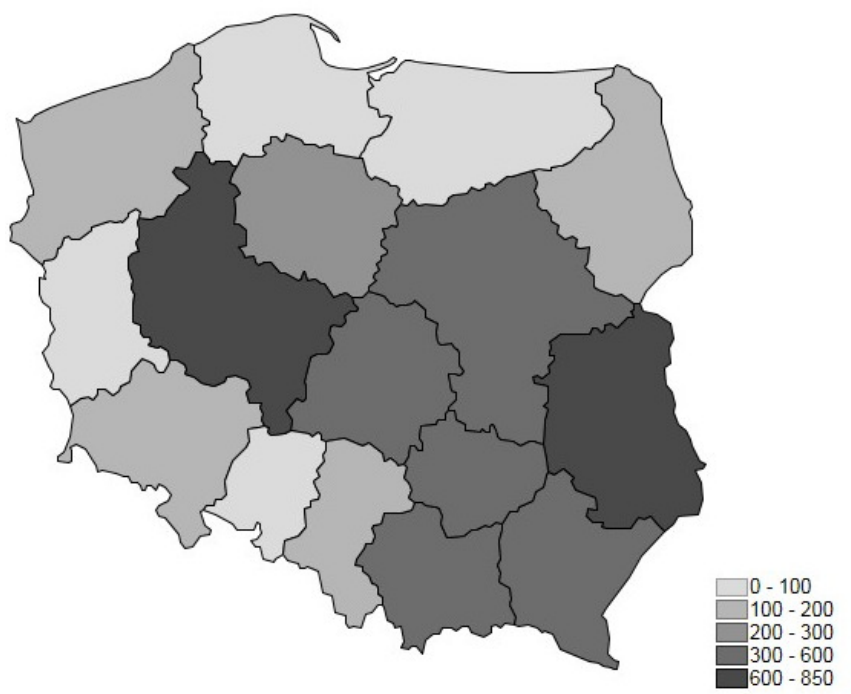

Source: author's calculations based on unpublished data of the Agency for Restructuring and Modernization of Agriculture [as on 10 January 2019]

Fig. 1. Number of FWAs in Poland

The study covered a total of 350 FWAs based in the Wielkopolskie voivodeship. This is the region with the largest number of active FWAs (847 as on 10 January 2019). Women in the 55-65 age bracket made up over $52.6 \%$ of FWA members. Most interviewees had a secondary or vocational education (57.8\%); one out of three respondents had a primary education (33.5\%); tertiary education levels were reported by only $8.7 \%$ of respondents. 
As shown by the study, rural women are socially active. The scope of their social activity varies in function of environmental and regional conditions. It also depends on the farm work cycle and on the seasons. Today's FWAs are organizations who autonomously choose their profile (e.g. cuisine, music, plastic arts, sports, theatre, education etc.) and fulfil continuous and temporary tasks for both the members and the entire local community. They cooperate with municipal councils $(78 \%)$, voluntary fire brigades (52\%), municipal cultural centres (41\%), educational institutions and nongovernmental organizations. The research revealed that FWA members living in rural areas are mostly active in four thematic areas. The first one is the promotion of regional or local products (culinary heritage). The second area was the support for cultural heritage in the area of handicrafts and traditional crafts, as well as preserving certain rituals and customs, e.g. Kupala Night ( $26 \%$ of FWAs surveyed). The third aspect of activity of female associations was the preservation of traditional natural landscape and biodiversity, i.e. growing native varieties of fruits, vegetables, flowers and herbs (16 \% of FWAs surveyed). The last area was related to socio-cultural and tourism activities. The interviewees usually emphasized the importance of local events, art festivals and tourist attractions located in their villages (Fig. 2).

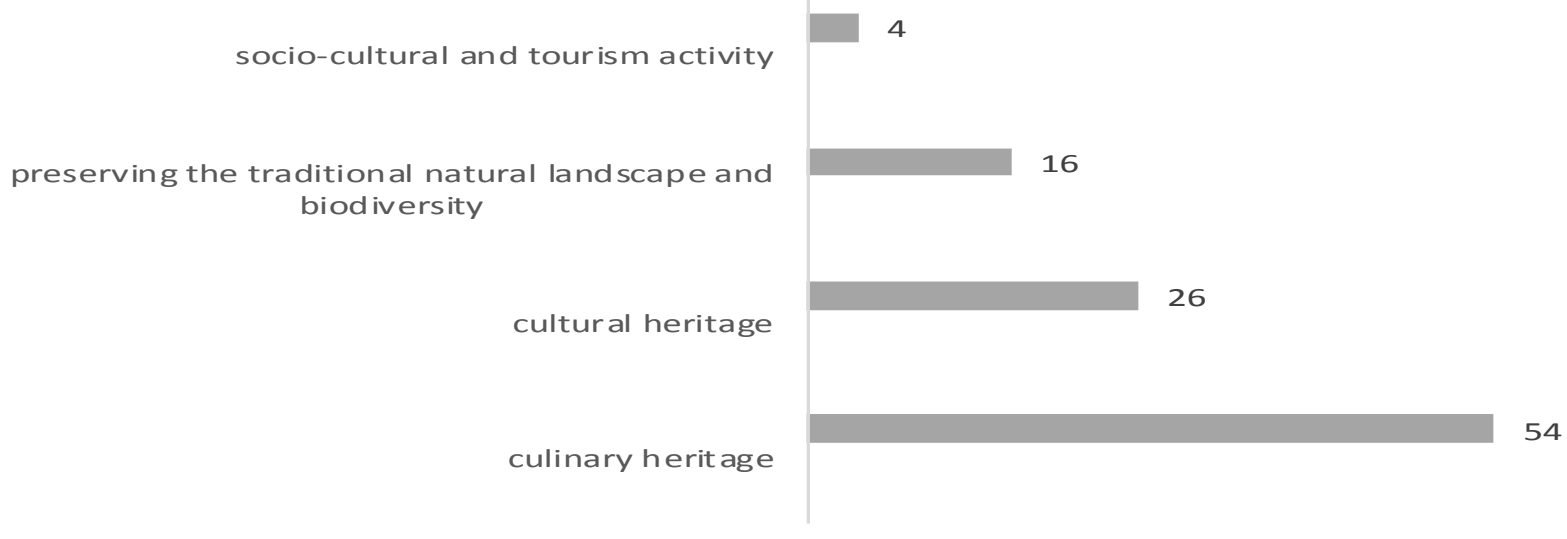

\section{Source: author's calculations}

Fig. 2. Activity of in rural women in FWAs in Wielkpolska region [ \%]

Later in the study, the FWAs were asked about their operating experience. It turns out that nearly $50 \%$ of FWAs in the Wielkopolskie voivodeship have been active for more than 21 years whereas $34 \%$ have been active for 11 to 20 years. The newest group of FWAs make up $17 \%$ of the entire sample and have been active for 1 to 10 years.

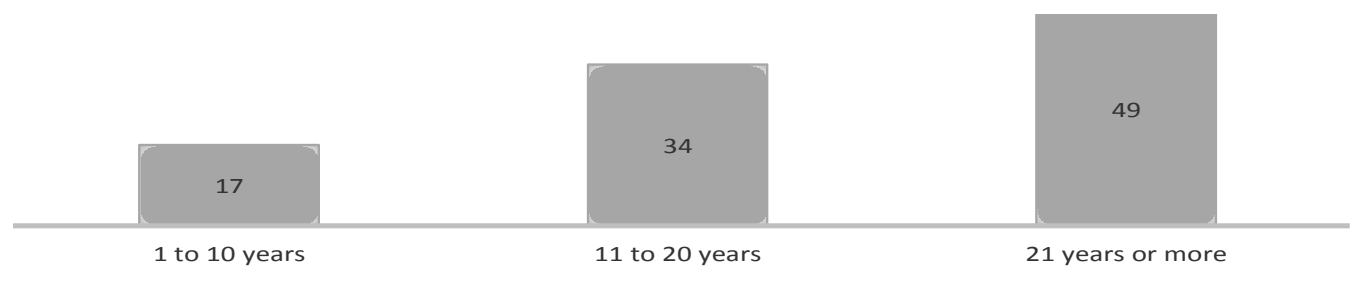

Source: author's calculations

Fig. 3. Years of activity of FWAs in Wielkopolska region [\%]

The FWAs offer an extremely broad range of products and services. The graph below shows the selected examples of products and services offered by FWAs in the Wielkopolskie voivodeship. 


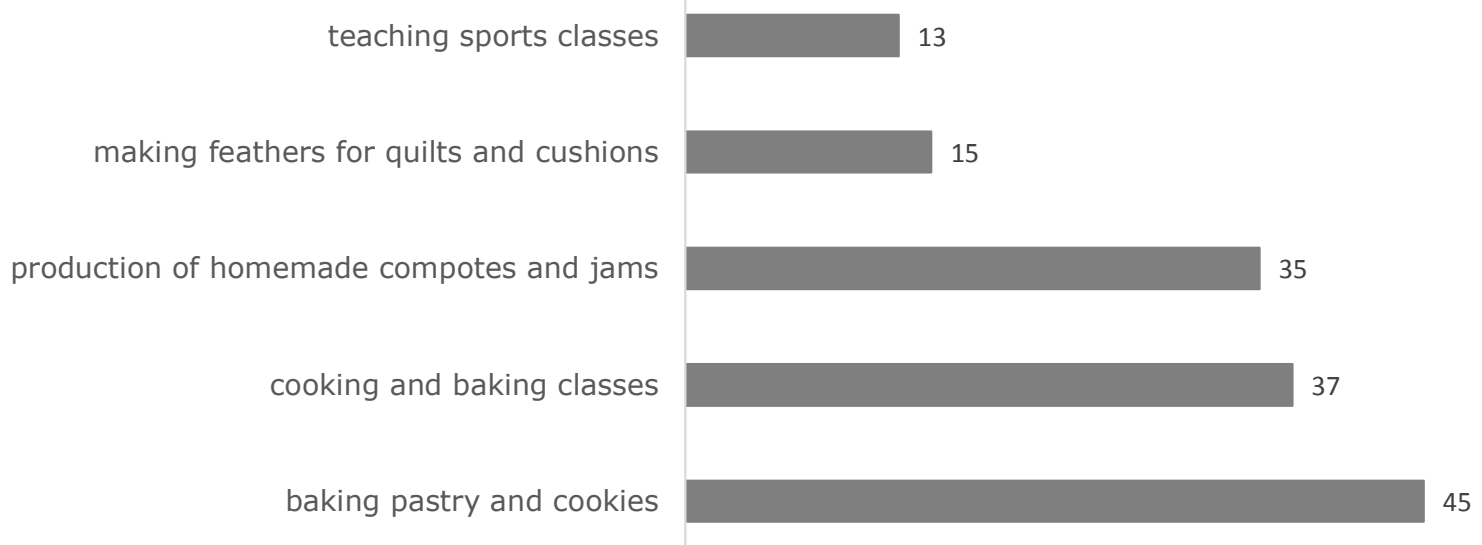

Source: author's calculations

Fig. 4. Range of products and services offered by FWAs in the Wielkopolskie voivodeship [\%]

According to this study, over $67 \%$ of FWAs are active in preparing festivals and cultural events. The key events supported by FWAs include: harvest festivals, Kupala night, Women's Day, Fat Tuesday, Potato Day. In an effort to preserve many popular and regional graphic designs, FWAs pay much attention to weaving and embroidery. Examples observed in the Wielkopolskie voivodeship include cutting out draperies of white parchment sheets. In turn, over $60 \%$ of FWAs are active in crafts and in the production of Catholic devotions available for sale during many rural events. FWAs based in Wielkopolska willingly organize cooking and baking classes. Their services also include the production of compotes and jams. For the public, this is an opportunity to taste pyry z gzikiem, duck roasted with apples, plyndze, szagówka, czernina, elderberry juice, quince nalewka etc. Other services offered by FWAs include making feathers for quilts, eiderdowns or cushions and teaching sports classes (13\%).

Currently, Polish women associated in FWAs are eligible for funding from the European Union. Since December 2018, the Republic of Poland has been implementing a dedicated measure to boost entrepreneurship among rural women. Essentially, this means that women register an FWA with the Agency for Restructuring and Modernization of Agriculture and, following this, apply for a subsidy from the Agency. The amount of aid depends on the number of members, as provided for in the National Register of Farmers' Wives' Associations (Table 1).

Amount of aid available to FWAs in Poland in 2019

\begin{tabular}{|l|c|c|}
\hline No. & Number of members & Amount of aid [PLN] \\
\hline 1. & up to 30 & 3000 \\
\hline 2. & from 31 to 75 & 4000 \\
\hline 3. & above 75 & 5000 \\
\hline
\end{tabular}

Source: author's calculations based on the Regulation of the Minister of Investments and Development of 28 November 2018 (Journal of Laws [Dz.U.], item 2229)

As shown by this study, nearly $60 \%$ of FWAs located in the Wielkopolskie voivodeship are part of the second group with 31 to 75 members. The funds (PLN 4,000) applied for by the women are planned to be allocated to several activities (Fig. 5). The subsidy will be mainly used to: equip community centres with modern household appliances ( $83 \%)$, purchase furniture $(43 \%)$, purchase 
cookware $(32 \%)$, promote handicrafts $(12 \%)$, promote regional foods $(31 \%)$, purchase plant and herb seedlings ( $9 \%)$, prepare rural events, e.g. dożynki, Potato Day, Kupala Night (7 \%) etc.

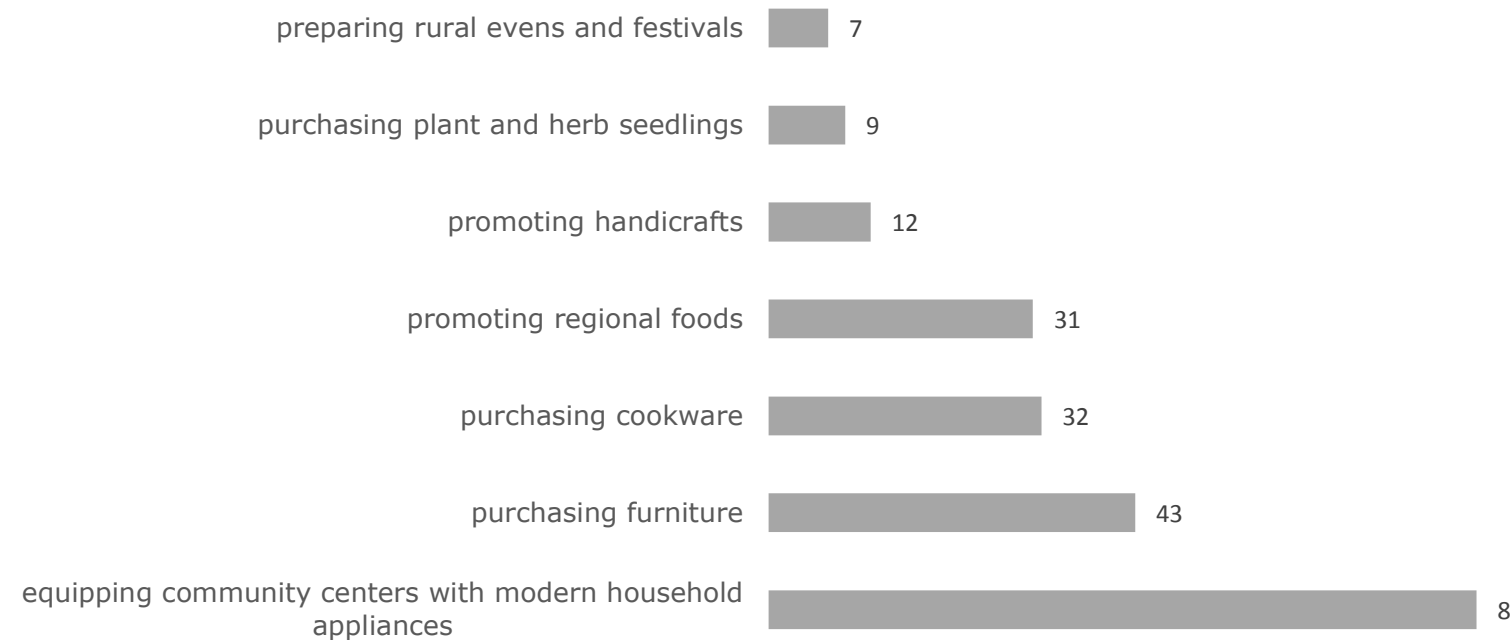

\section{Source: author's calculations}

Fig. 5. Allocation of EU subsidies granted to FWAs in Wielkopolska region [ \%]

Note however that the projects intended to be implemented by the women contribute to improving competitiveness and entrepreneurship and to earning additional income from non-agricultural activities.

\section{Conclusions, proposals, recommendations}

Upon joining the European Union in 2004, Poland became eligible for additional financial support for rural development. In the context of the 2014-2020 Rural Development Program, access to funds allocated to the development of female rural entrepreneurship is of particular importance. Entrepreneurship in rural areas is seen as a way of stimulating action and gaining an additional source of income. Moreover, it gives an opportunity to become independent from social assistance, improve the quality of life and raise the standard of living of farmers and their families. Currently, in rural areas it can be seen that women in rural areas organise themselves and are active in different ways. Entrepreneurship of women living in rural areas is characterised by specificity. In Europe, on average, one in five farms is run by a woman. In the EU Member States, 13.7 million people worked permanently or temporarily in agriculture, of which 12.2 million were family members, 38 percent of whom were women (Report). Szepelska (2014) indicated that in the EU countries the economic activity of women in urban areas is higher than in rural areas. The highest participation rate of women from rural areas is in Sweden (68.7 \%) and the lowest in Italy (45.4 \%). Poland has a rate of $51.5 \%$. It is worth noting that Poland has a relatively high rate of self-employment of women. One of the possibilities of activating women in rural areas in Poland is the creation of FWAs. Funds financed by women will allow for building a local development strategy, as well as give an opportunity to have a real influence on the development of this area. In many scientific publications in Poland and abroad, such as Balinska (2014), Wojcieszak (2018), Poczta (2017), Poczta (2014), Kiryluk et al. (2018), it is stressed that the village is to be a place of work and residence, thanks to its high natural values and the creation of new jobs, it requires external support, which are certainly EU funds. The creation of the FWAs is an element of the concept of the so-called sustainable agriculture, which combines the idea of multifunctional agriculture and service and social agriculture. The idea of creating and 
functioning of the FWAs may be a great opportunity to promote the region in the future, because firstly, it may generate additional income for these regions and secondly, the development of services, production of products and their sale by women associated in the FWAs may be a way to overcome the negative social and economic phenomena in rural areas. The functioning of the KGW and their creative activation increases women's sense of efficiency and entrepreneurship, which, in turn, allows them to enter public life and build a civil society. Therefore, it is important for the common agricultural policy to continue to maintain measures focused on the development of women in rural areas.

\section{Bibliography}

1. Act of October 8, 1982 on Social and Professional Organizations of farmers, Journal of Laws (Dz.U.) of 1982, No. 32, item 217

2. Act of November 9, 2018 on the Farmers' Wives' Associations (Dz.U.) poz. 2229

3. Balinska, A. (2017). Turystyka wiejska w kontekście teorii rozwoju endogenicznego (Rural tourism in the context of the theory of endogenous development). SERIA. No XVIII, 2. pp. 21-26.

4. Banski J. (2015). Uwarunkowania rozwoju przedsiębiorczości na wsi- wybrane zagadnienia (Conditions for the development of entrepreneurship in rural areas - selected issues). Roczniki Naukowe Ekonomii Rolnictwa i Rozwoju Obszarów Wiejskich. No. 102(1).

5. Central Statistical Office. (2017). http://stat.gov.pl/. Access:11.01.2019.

6. Davidova, S., Gorton, M., Fredriksson, L. (2010). Niskotowarowa gospodarka rolna w Europie. Raport "Niskotowarowa gospodarka rolna w UE: sytuacja dzisiaj i perspektywy na przyszłość"( Low-input farming in Europe. Report for the seminar "Low-input farming in the EU: situation today and prospects for the future). Sibiu-Rumunia. 13-15.10.2010.

7. Dyjach, K. (2013). Teorie rozwoju regionalnego wobec zróżnicowań międzyregionalnych (Theories of regional development in the face of interregional disparities). Annales Universitatis Mariae Curie-Skłodowska Lublin-Polonia. Sectio H XLVII. pp. 50-51.

8. Gender in agriculture and rural development (2016). Luxembourg: European Institute for Gender Equality. Publications Office of the European Union.

9. Kaminska, W. (2011). Aktywność gospodarcza osób fizycznych na obszarach wiejskich w Polsce (Economic activity of natural persons in rural areas in Poland), [in:] W. Kaminska, K. Heffner (ed.), Obszary wiejskie. Wielofunkcyjność, migracje, nowe wizje Rozwoju (Rural areas. Multifunctionality, migration, new visions Developments). KPZK PAN. No. 133. pp. 103-127.

10. Kiryluk-Dryska, E., Beba, P., Wojcieszak, M. (2018). Czynniki wpływające na aktywność rolników w ubieganiu się o wsparcie z działania ułatwianie startu młodym rolnikom w województwie wielkopolskim (Factors influencing farmers' activity in applying for support from the measure facilitating the start of young farmers in Wielkopolskie voivodship). Zagadnienia Ekonomiki Rolnej. 4/2018. No. 357. pp. 103-116.

11. Komisja Europejska. 2014. Rozwój lokalny kierowy przez społeczności. Polityka Spójności na lata 20142020. (European Commission. Local development by communities. Cohesion policy for 2014-2020). European Commission, ec.europa.eu. [11.12.2018]

12. Kozera, M. (2015). Efektywność wykorzystania kapitału intelektualnego przedsiębiorstw rolniczych w Polsce (Effectiveness of the use of intellectual capital of agricultural enterprises in Poland). Roczniki Naukowe Ekonomii Rolnictwa i Rozwoju Obszarów Wiejskich. No. 102(2).

13. Kozera, M. (2014). Efektywność wykorzystania kapitału intelektualnego w przedsiębiorstwachrolniczych Wielkopolski Effectiveness of the use of intellectual capital in companies agricultural Wielkopolska).Przedsiebiorczość i Zarządzanie. No. XV(6). pp. 165-179.

14. Kutkowska, B., Pilawka, T. (2012). Program odnowy wsi jako instrument wzbogacający jakość kapitału społecznego (Rural renewal programme as an instrument to enhance quality social capital). Roczniki Naukowe SERIA XIV (3). pp. 232-237.

15. Michalska, S. (2012). Social aspects of the functioning of small farms, Problems of Small Agricultural Holdings. No. 1. pp. 85-93.

16. Piers Thompson, Jones-Evans, D., Kwong, C. (2009). Women and Home-based Entrepreneurship: Evidence from the United Kingdom. International Small Business Journal:Researching Entrepreneurship, Volume 27, 2, pp. 227-239.

17. Poczta, W. (2010). Wspólna polityka rolna UE po 2013 roku - uzasadnienie, funkcje, kierunki rozwoju w kontekście interesu polskiego rolnictwa (Common Agricultural Policy of the EU after 2013 - justification, functions, directions of development in the context of the interest of Polish agriculture). Wieś $i$ Rolnictwo. No. 3. pp. 38-55.

18. Report Policy Brief on Women's Entrepreneurship (2016). Luxembourg: Publications Office of the European Union.

19. Raport z badania Sytuacja kobiet w rolnictwie i na obszarach wiejskich. Specyfika, standardy, parytety (Research report Situation of women in agriculture and rural areas. Specifications, standards, 
parities)(2012). Warszawa: MRiRW, Konsorcjum Badawcze Focus Group Albert Terelak, Centrum Rozwoju SpołeczNo Gospodarczego Sp. z o.o.

20. Sawicka, J. (2009). Sytuacja kobiet wiejskich na rynku pracy i w rolnictwie (Situation of rural women in the labour market and agriculture), [in:] Piotrowska. J, Grzybek. A. (ed.).: Raport. Kongres kobiet Polskich 2009. Kobiety dla Polski, Polska dla Kobiet. 20 lat transformacji 1989-2009 (Report. Congress of Polish Women 2009: Women for Poland, Poland for Women. 20 years of transformation 1989-2009.). Fundacja Feminoteka. Warsaw.

21. Sikorska-Wolak, I., Krzyzanowska, K. (2010). Przedsiębiorczość w ujęciu teoretycznym i w praktyce, [in] K. Krzyzanowska (red.), Przedsiębiorczość na obszarach wiejskich. Stan i perspektywy rozwoju (Entrepreneurship in rural areas. State and prospects for development), SGGW, Warszawa.

22. Situation of women in agriculture and rural areas. Specifics, standards, parities and expectations," a report by the FOCUS GROUP - CRSG, 2012; Report on the situation of women in rural areas of the EU (2007/2117(INI))) European Parliament.

23. Szapelska, A.(2014). Bariery przedsiębiorczości kobiet zamieszkujących obszary wiejskie (Barriers to entrepreneurship for women living in rural areas). Zeszyty Naukowe Ostrołęckiego Towarzystwa Naukowego. No. 28. pp. 290-300.

24. Tabor, K. (2010). Przestrzeń doradztwa i przedsiębiorczości na obszarach wiejskich (Advisory and entrepreneurial space in rural areas), [in] K. Krzyzanowska (red.), Przedsiębiorczość na obszarach wiejskich. Stan i perspektywy rozwoju (Entrepreneurship in rural areas. State and prospects for development). SGGW. Warsaw. pp. 125-141.

25. Wojcieszak, M. (2018). Welfare farms in Poland as an example of entrepreneurial activities in rural areas, Proceedings of the 2018 International Scientific Conference „Economic Sciences for Agribusiness and Rural Economy" SGGW. No 2. pp. 161-166. 